\title{
Effect of high plane of nutrition on the performance of Haemonchus contortus infected kids
}

\author{
A. K. Pathak, S. P. Tiwari \\ Department of Animal Nutrition, \\ College of Veterinary Science \& AH, Anjora, Indira Gandhi Agricultural University, Durg, Chhattisgarh, India \\ Corresponding author email: A. K. Pathak, email: dranand_pathak@yahoo.com, drakp_74@rediffmail.com \\ Received: 22-05-2012, Accepted: 05-06-2012, Published online: 05-11-2012
}

\begin{abstract}
How to cite this article:
Pathak AK and Tiwari SP (2013) Effect of high plane of nutrition on the performance of Haemonchus contortus infected kids, Vet World 6(1):22-26. doi: 10.5455/vetworld.2013.22-26
\end{abstract}

\begin{abstract}
Aim: To determine the effect of severity of Haemonchus contortus infection on performance and economics of raising kids fed on two respective plane of nutrition.

Materials and Methods: The feeding trial was conducted for 120 days with non-descript female kids (3-5 months age). The kids were randomly allocated into two dietary treatments having normal protein normal energy (NPNE) and high protein medium energy (HPME) using conventional feedstuffs (crushed maize, ground nut cake, berseem hay and chaffed paddy straw), fortified with mineral mixture (1\%), salt (0.5\%) and vitamin premix (@ 20gq ${ }^{-1}$ feed), each treatment having three levels of $H$. contortus infection $\left(\mathrm{W}_{0}, \mathrm{~W}_{500}\right.$ and $\left.\mathrm{W}_{2000}\right)$ in a $2 \times 3$ factorial design. The study was undertaken to ascertain the performance and economics of raising kids fed on higher plane of nutrition.

Results: The total dry matter intake (DMI: $\mathrm{kg}$ ) was $41.18,39.56$ and 41.11 in $\mathrm{W} 0, \mathrm{~W}_{500}$ and $\mathrm{W}_{2000}$ in group HPME; whereas in NPNE the DMI was $39.66,38.03$ and $35.95 \mathrm{~kg}$ in the respective infection levels. The highest body weight gain was obtained in HPME than NPNE from $1^{\text {st }}$ to $16^{\text {th }}$ week of experiment. The infected kids at NPNE gained at a slower rate as compared to the kids maintained at HPME. The mean percentage of monocytes, lymphocytes and neutrophils fluctuated in different ways throughout the experiment without any significant difference and these cells were not followed any specific trend. However, significantly higher $(\mathrm{P}<0.05)$ eosinophils count was recorded in $\mathrm{W}_{500}$ and $\mathrm{W}_{2000}$ of HPME fed kids as compared to $\mathrm{W}_{500}$ and $\mathrm{W}_{2000}$ of NPNE fed kids. In the present study the maximum benefit could be obtained by feeding of HPME diet with $\mathrm{W}_{500}$ infection as compared to other treatments.
\end{abstract}

Conclusions: The cost of raising kids per kg meat was worked out to be the most economical at high plane of nutrition even with the heavy $H$. contortus infection.

Keywords: economics, Haemonchus contortus infection; kids, performance, plane of nutrition

\section{I ntroduction}

The recurring losses in productivity and profit due to Haemonchus contortus infection are a common problem for small ruminants' production in the most part of the world [1-7]. This condition becomes worse in the malnourished animals. This shows a significant relationship between nutrition and infection. Enhanced nutrition can affect the ability of the host to cope with the consequences of parasitism and to tolerate or overcome parasitism [8-12]. Many workers [13-15] have demonstrated that parasitic infestation adversely reduced DMI in small ruminants and that was improved by high quality feed supplementation [16]. Similarly, highly metabolizable protein diets have been shown to increase resistance of lambs against $H$. contortus [17]. Well-fed animals can withstand the harmful effects of GI parasitism, can remain reasonably productive and may require less anthelmintic treatments when compared with undernourished animals [18,19]. On high plane of nutrition, animals do not have to repartition protein from productive functions such as muscle, bone and wool growth towards repair functions of the GI tract, plasma and blood replacement [8]. A more recent update of the implications and interactions of nutrients and parasites in small ruminants have been discussed by Jackson [20], Athanasiadou et al. [21], as well as with an emphasis in goats by Hoste et al. [22].

However, this field of investigation is still unexplored which needs to be exploited for the better health of the animals. Therefore this field has been considered to be a recent trend to find out a suitable performance index of parasitized animals. It would provide a proficient indication to develop a novel feed formula for the animals in accordance with intensity of parasitic infections. Keeping this in view, the present study was planned to ascertain the effect of severity of $H$. contortus infection on performance and economics of raising kids fed on high plane of nutrition.

\section{Materials and Methods}

Twenty four non-descript goat kids (3-5 months) were randomly allocated into six equal groups. Two diets normal protein normal energy (NPNE) and high protein medium energy (HPME) were fed to kids 
Table- 1. Differential leucocytes count (\%) of kids fed on different diets with $\mathrm{H}$. contortus

\begin{tabular}{|c|c|c|c|c|c|c|c|c|}
\hline Parameters & $\begin{array}{l}\text { Periods } \\
\text { (Weeks) }\end{array}$ & $\mathbf{W}_{0}$ & $\begin{array}{c}\text { Infectio } \\
W_{500}\end{array}$ & $\mathbf{W}_{2000}$ & SEM & NPNE & HPME & SEM \\
\hline \multirow[t]{6}{*}{ Monocytes } & $3^{\text {rd }}$ & 2.25 & 2.62 & 2.75 & 0.60 & 2.67 & 2.42 & 0.49 \\
\hline & $4^{\text {th }}$ & 1.25 & 1.37 & 1.25 & 0.39 & 1.17 & 1.42 & 0.32 \\
\hline & $5^{\text {th }}$ & 1.50 & 1.62 & 1.25 & 0.40 & 1.17 & 1.75 & 0.32 \\
\hline & $6^{\text {th }}$ & 1.87 & 1.50 & 2.00 & 0.34 & 1.50 & 2.08 & 0.28 \\
\hline & $7^{\text {th }}$ & 1.62 & 2.25 & 2.50 & 0.25 & 2.00 & 2.25 & 0.20 \\
\hline & $8^{\text {th }}$ & 2.12 & 2.25 & 2.25 & 0.49 & 1.92 & 2.50 & 0.40 \\
\hline \multirow[t]{6}{*}{ Lymphocytes } & $3^{\text {rd }}$ & 61.50 & 57.37 & 56.50 & 1.88 & 59.08 & 57.83 & 1.53 \\
\hline & $4^{\text {th }}$ & 60.87 & 55.12 & 55.87 & 1.82 & 57.75 & 56.83 & 1.48 \\
\hline & $5^{\text {th }}$ & 59.75 & 52.25 & 57.50 & 2.52 & 58.83 & 54.17 & 2.05 \\
\hline & $6^{\text {th }}$ & 57.75 & 54.75 & 53.25 & 2.32 & 57.67 & 52.83 & 1.89 \\
\hline & $7^{\text {th }}$ & 53.00 & 55.25 & 50.00 & 1.62 & 52.83 & 52.67 & 1.32 \\
\hline & $8^{\text {th }}$ & 59.75 & 54.87 & 51.12 & 2.11 & 55.92 & 54.58 & 1.30 \\
\hline \multirow[t]{6}{*}{ Neutrophils } & $3^{\text {rd }}$ & 34.75 & 28.87 & 26.87 & 1.65 & 30.08 & 30.25 & 1.34 \\
\hline & $4^{\text {th }}$ & 36.37 & 35.00 & 32.00 & 2.24 & 35.00 & 33.92 & 1.83 \\
\hline & $5^{\text {th }}$ & 38.00 & 35.37 & 32.12 & 2.48 & 35.00 & 35.33 & 2.03 \\
\hline & $6^{\text {th }}$ & 40.87 & 36.75 & 36.00 & 1.91 & 37.42 & 38.33 & 1.56 \\
\hline & $7^{\text {th }}$ & 43.50 & 38.25 & 39.00 & 1.59 & 42.25 & 38.25 & 1.30 \\
\hline & $8^{\text {th }}$ & 37.25 & 34.12 & 38.75 & 1.84 & 38.25 & 35.17 & 1.50 \\
\hline \multirow[t]{6}{*}{ Eosinophils } & $3^{\text {rd }}$ & $1.50^{\mathrm{a}}$ & $11.12^{b}$ & $13.87^{c}$ & 0.83 & 8.17 & 9.50 & 0.68 \\
\hline & $4^{\text {th }}$ & $1.50^{\mathrm{a}}$ & $8.50^{b}$ & $10.87^{c}$ & 0.52 & $6.08^{A}$ & $7.83^{\mathrm{B}}$ & 0.42 \\
\hline & $5^{\text {th }}$ & $0.75^{\mathrm{a}}$ & $10.75^{b}$ & $9.12^{c}$ & 0.63 & $4.92^{\mathrm{A}}$ & $8.83^{B}$ & 0.51 \\
\hline & $6^{\text {th }}$ & $0.75^{\mathrm{a}}$ & $8.87^{b}$ & $8.75^{c}$ & 0.66 & $4.50^{A}$ & $7.75^{\mathrm{B}}$ & 0.54 \\
\hline & $7^{\text {th }}$ & $0.62^{a}$ & $8.75^{b}$ & $8.25^{c}$ & 0.68 & $4.17^{A}$ & $7.58^{B}$ & 0.55 \\
\hline & $8^{\text {th }}$ & $0.87^{\mathrm{a}}$ & $8.75^{b}$ & $8.12^{c}$ & 0.51 & $3.92^{A}$ & $7.92^{\mathrm{B}}$ & 0.41 \\
\hline
\end{tabular}

a b c \& A B: Means with different superscripts differ significantly $(P<0.05)$

having three levels of $H$. contortus infection $\left(\mathrm{W}_{0}, \mathrm{~W}_{500}\right.$, $\mathrm{W}_{2000}$ ) in a $2 \times 3$ factorial design [23] for experimental period of 120 days.

The NPNE diet contained berseem hay and chopped rice straw as source of roughage in the ratio of 60:40 and crushed maize @ 100g/d/kid as source of concentrate ingredient. However, the HPME diet contained berseem hay and chopped rice straw in the ratio of 90:10 and crushed maize and groundnut cake (50:50) as concentrate. The diets were supplemented with mineral mixture $(1 \%)$, salt $(0.5 \%)$ and vitamin premix (20g/q feed). The diets were formulated on the basis of DCP and TDN requirement of kids for maintenance and growth as per NRC [24]. The formulated diets contained 7\% DCP and $57.3 \%$ TDN in NPNE while $13.15 \%$ DCP and $62.5 \%$ TDN in HPME.

All the kids were kept under uniform managemental conditions by housing them in a well-ventilated shed with facilities for individual feeding. All kids were dewormed and vaccinated according to standard protocol before the start of experiment. The feeding trial was lasted for 120 days. Daily record of feed intake was done. All kids were weighed weekly at three consecutive days during the entire experiment. Daily gain in body weight of kids was determined by subtracting the initial body weight from the final body weight. The blood samples were collected from all kids after giving three weeks of infection. The collection was done at weekly interval till the $8^{\text {th }}$ week post infection. Blood smears were prepared immediately after blood collection. It was stained with Leishman's stain. Thereafter counting was done for Neutrophils, Basophils, Eosinophils and lymphocytes.

\section{Ethical Consideration:}

Permission of the Institutional Animal Ethics
Committee was taken prior to start of the experimental study.

\section{Results and Discussion}

The average dry matter intake $\left(\mathrm{gd}^{-1}\right)$ of entire feeding trial at weekly interval in various groups has been presented in Fig1. The difference between NPNE and HPME was found to be significant at $2^{\text {nd }}$ week. The same trend maintained till the end of the experiment except on $5^{\text {th }}$ week. Significantly $(\mathrm{P}<0.05)$ higher DMI was reported in HPME than that of in NPNE. No significant difference was observed between different level of infection $\left(\mathrm{W}_{0}, \mathrm{~W}_{500}\right.$ and $\left.\mathrm{W}_{2000}\right)$ at varying levels of nutrition (NPNE and HPME) before the administration of $H$. contortus infection. However, it was statistically significant after $5^{\text {th }}$ week post infection and till the end of experiment. The highest DMI was obtained in $\mathrm{W}_{0}$ kids followed by $\mathrm{W}_{500}$ and lowest in $\mathrm{W}_{2000}$ kids. The DMI in $\mathrm{W}_{2000}$ kids of NPNE group was found to be drastically reduced at $3^{\text {rd }}$ week post infection on ward as compared to $\mathrm{W}_{2000}$ kids of HPME. As the period of infection increased the DMI was also increased but in $\mathrm{W}_{2000}$ and $\mathrm{W}_{500}$ kids it was not increased as that of kids without infection.

The initial and final body weight $(\mathrm{kg})$, total body weight gain $(\mathrm{kg})$ and body weight gain $\left(\mathrm{gd}^{-1}\right)$ at weekly interval during the entire experiment (120 days) were presented in Table-2 and Fig-2. Difference in body weight gain $(\mathrm{P}<0.05)$ between NPNE and HPME kids was started early in the experiment but it was only pronounced after $3^{\text {rd }}$ week post infection. It was noted that the differences of weight gain between NPNE and HPME fed kids were statistically significant at the time of zero infection. Within NPNE, the differences in 
Table-2. Least square means for different parameters of kids fed on diets at varying level of $H$. contortus infection

\begin{tabular}{|c|c|c|c|c|c|c|}
\hline \multirow[t]{2}{*}{ Parameters } & \multicolumn{3}{|c|}{ NPNE } & \multicolumn{3}{|c|}{ HPME } \\
\hline & $\mathbf{w}_{0}$ & $\mathbf{W}_{500}$ & $\mathbf{W}_{2000}$ & $\mathbf{W}_{0}$ & $\mathbf{W}_{500}$ & $\mathbf{W}_{2000}$ \\
\hline Initial body weight (kg) & 11.04 & 11.06 & 11.05 & 11.03 & 11.04 & 11.06 \\
\hline Final body weight (kg) & $14.72^{\mathrm{bA}}$ & $13.48^{\mathrm{aA}}$ & $12.64^{\text {aA }}$ & $15.80^{\mathrm{bB}}$ & $14.56^{\mathrm{aB}}$ & $13.73^{\mathrm{aB}}$ \\
\hline $\begin{array}{l}\text { Total DMI }(\mathrm{kg}) \\
\text { Cost of feed (Rs/kg) }\end{array}$ & $39.66^{A}$ & $38.03^{\mathrm{A}}$ & $35.95^{\mathrm{A}}$ & $41.18^{\mathrm{B}}$ & $39.56^{\mathrm{B}}$ & $41.11^{\mathrm{B}}$ \\
\hline Concentrate & 12.10 & 12.10 & 12.10 & 12.30 & 12.30 & 12.30 \\
\hline Roughage & 2.20 & 2.20 & 2.20 & 3.00 & 3.00 & 3.00 \\
\hline Total cost (Rs) & 194.17 & 190.59 & 186.01 & 223.98 & 219.12 & 223.77 \\
\hline Total body weight gain $(\mathrm{kg})$ & $3.68^{\mathrm{cA}}$ & $2.42^{\mathrm{bA}}$ & $1.59^{\mathrm{aA}}$ & $4.77^{\mathrm{CB}}$ & $3.52^{\mathrm{BB}}$ & $2.67^{\mathrm{aB}}$ \\
\hline Total cost of meat (Rs) & $368^{\mathrm{cA}}$ & $242^{\mathrm{bA}}$ & $159^{\mathrm{aA}}$ & $477^{\mathrm{cB}}$ & $352^{\mathrm{bB}}$ & $267^{\mathrm{aB}}$ \\
\hline Feeding cost/ Kg meat (Rs) & $52.76^{\mathrm{aA}}$ & $78.76^{\mathrm{bA}}$ & $117.00^{\mathrm{cA}}$ & $46.95^{\mathrm{aB}}$ & $62.25^{\mathrm{bB}}$ & $83.81^{\mathrm{CB}}$ \\
\hline Profit / loss (Rs) & $172.83^{\mathrm{cA}}$ & $51.41^{\mathrm{bA}}$ & $-27.01^{\mathrm{aA}}$ & $253.02^{\mathrm{cB}}$ & $132.88^{\mathrm{bB}}$ & $43.23^{\mathrm{aB}}$ \\
\hline Cost of dewormer (Rs) & - & 11.90 & 23.80 & - & 11.9 & 11.9 \\
\hline $\begin{array}{l}\text { Total expenditure (Rs) } \\
\text { (Feed + dewormer cost) }\end{array}$ & $173.83^{\mathrm{aA}}$ & $202.49^{\text {bA }}$ & $209.81^{\mathrm{bA}}$ & $253.02^{\mathrm{bB}}$ & $231.02^{\mathrm{aB}}$ & $235.67^{\mathrm{aB}}$ \\
\hline Net profit / loss (Rs) & 173.83 & $39.51^{\mathrm{bA}}$ & $-50.81^{\mathrm{aA}}$ & $253.02^{\mathrm{cB}}$ & $120.98^{\mathrm{bB}}$ & $31.33^{\mathrm{aB}}$ \\
\hline
\end{tabular}

Cost of meat was considered at the local market price of Rs $100 / \mathrm{kg}$.

$a b c \& A B$ : Means with different superscripts differ significantly $(P<0.05)$

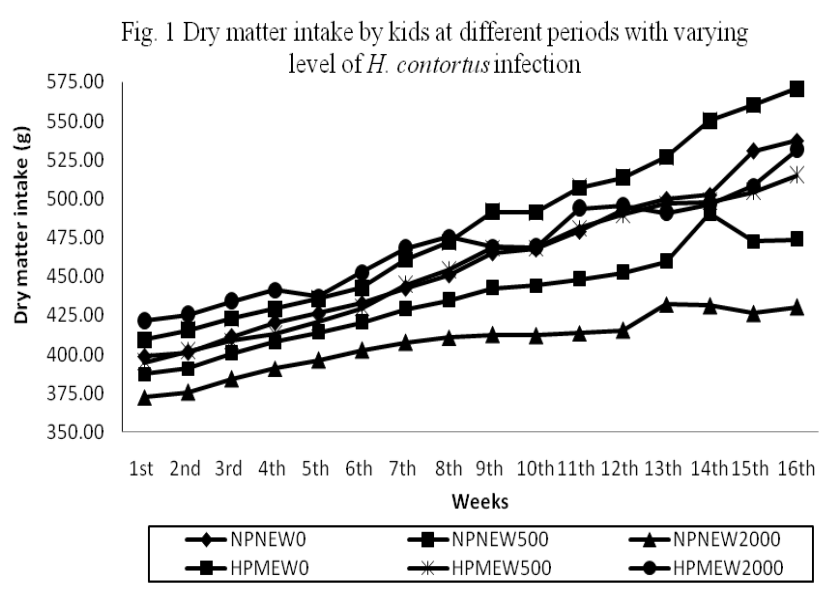

body weight gain due to $\mathrm{W}_{500}$ and $\mathrm{W}_{2000}$ infections were more. However, within HPME these differences were not so large. This was due to compensatory growth of kids because of HPME diet. The daily body weight gain was found to be highest in $\mathrm{W}_{0}$ followed by $\mathrm{W}_{500}$ and $\mathrm{W}_{2000}$. The interaction between diets and infection differ significantly $(\mathrm{P}<0.05)$ only after $5^{\text {th }}$ week post infection.

The data of DLC from $3^{\text {rd }}$ to $8^{\text {th }}$ week post infection of kids fed on different diets are presented in Table-1. The values of monocytes, lymphocytes and neutrophils fluctuated in different ways and these cells were not followed any specific trend. These values were with in the normal physiological range. The mean percentage of monocytes was found to be maximum in HPME than that of NPNE during the entire experiment but it was found statistically non significant. The difference between dietary treatment, levels of infection and their interaction were statistically non significant. Similar observation was also reported by earlier worker [13] in $H$. contortus infected sheep. Although the eosinophils count was found statistically significant in NPNE and HPME with the various levels of infection $\left(\mathrm{W}_{0}, \mathrm{~W}_{500}\right.$ and $\left.\mathrm{W}_{2000}\right)$. The maximum eosinophils count was obtained in $\mathrm{W}_{500}$ and $\mathrm{W}_{2000}$ where kids were fed HPME diet as compared to $\mathrm{W}_{500}$ and $\mathrm{W}_{2000}$ where there kids fed NPNE diet. Earlier workers [25] also reported increased

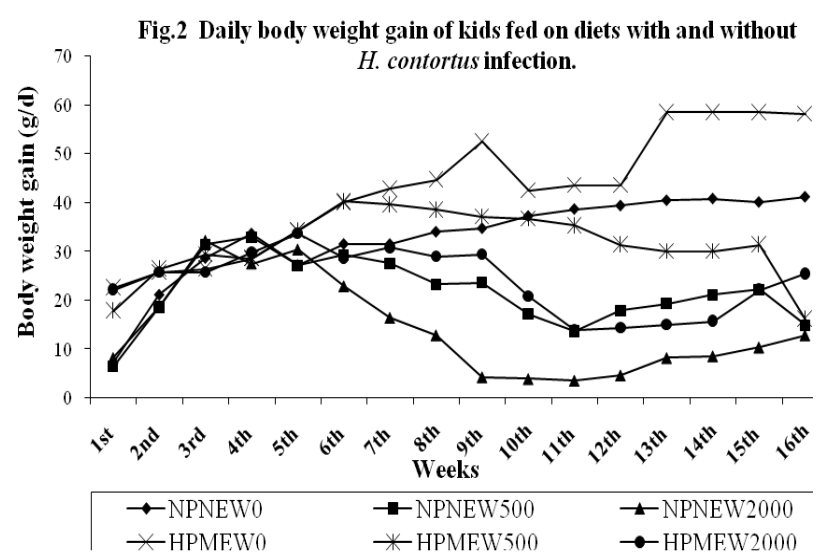

concentration of eosinophils in Trichostrongylus. colubriformis infected lambs supplemented with fish meal. In accordance to the earlier report [26] in Nematodirus battus and $H$. contortus infected sheep where high protein intake significantly increased eosinophil numbers [27]. Eosinophils have been used as selection indices for breeding sheep with an enhanced resistance to parasites [28,29]. Various workers [30,31] suggested that pro-inflammatory cytokines are linked to alterations in nutrient uptake and utilization.

The economics of raising kids with varying level of nutrition under different intensity of $H$. contortus infection have been given in Table-2. It was observed that HPME fed kids gained more body weight as compared to NPNE. It was found to be higher in control kids $\left(\mathrm{W}_{0}\right)$ than in $\mathrm{W}_{500}$ infected kids and least gain was recorded in $\mathrm{W}_{2000}$ kids. In earlier report it was found that the $H$. contortus infected kids [32] and lambs [27] gained more weight when given high protein diet than low protein diet. The depression in intake was accounted for over $60 \%$ of the difference in weight gain between T. colubriformis infected and control [33] while about $73 \%$ of difference in weight gain between O. ostertagi infected and ad-lib fed control calves [34]. Similar studies had shown that during infection with $H$. contortus kids [32] and sheep [35,36] offered a high 
protein diet attained a more live weight gains than those offered a low protein diet. The rate of expulsion of gastrointestinal nematode parasites was related to the level of supplementation [25]. Protein supplementation had beneficial effect on both resistance and resilience of dairy goats to nematode trickle infection [37]. The faecal egg counts were lowered and eosinophil counts were higher in the animals receiving the high protein diet. Supplementation of metabolizable protein enhanced the resistance to infection from $T$. colubriformis in lambs [38]. Immunomanipulation through optimized nutrition [21,39] offers some advantage in reducing the numbers of anthelmintic treatments that animals require. Host acquired immunity is one the most important factors influencing epidemiological differences between the various gastrointestinal nematode parasites and the host plane of nutrition is a crucial element that influences its development and maintenance [5]. Therefore the result of the present study suggested that the diet fed to kids with HPME, tended to ameliorate the adverse effect of H. contortus infection $\left(\mathrm{W}_{500}\right.$ and $\left.\mathrm{W}_{2000}\right)$. The higher protein level improved daily gain in body weight in kids. The feeding cost per $\mathrm{kg}$ meat produced was found to be reduced due to feeding of HPME diet as compared to NPNE diet. It was worked out to be Rs. $46.95,62.25$, 83.81 per $\mathrm{kg}$ meat in HPME against Rs 52.76, 78.76 and 117.00 per $\mathrm{kg}$ meat in NPNE at three levels $\left(\mathrm{W}_{0}\right.$, $\mathrm{W}_{500}$ and $\mathrm{W}_{2000}$ ) of infection respectively. The maximum benefit could be obtained by feeding of HPME diet with $\mathrm{W}_{500}$ infection as compared to any other level of infection either with HPME or NPNE diet. In this way there is a clear cut saving of at least Rs 16.51 per $\mathrm{kg}$ of meat. This might be due to the compensatory growth of kids in HPME due to supply of additional protein and energy resulting into fast recovery in such diet. The kids fed NPNE diet with $\mathrm{W}_{2000}$ infection required repeated deworming which increased the total cost of kid raising. However in HPME group no further deworming was done.

\section{Conclusions}

It may be concluded that the increased number of eosinophils in HPME fed kids during $H$. contortus infection may provide an index of a protective immune response of kids to $H$. contortus infection. The infected kids at the normal levels of dietary protein and energy gained at a slower rate as compared to the kids maintained at a higher level of protein and energy. The cost of raising kids per kg meat was worked out to be the most economical at high plane of nutrition even with the heavy infection.

\section{Author's contribution}

Both author contributed equally. Both author read and appproved the final manuscript.

\section{Acknowledgements}

The authors are highly thankful to Dean, College of Veterinary Science and Animal Husbandry, Indira Gandhi Agricultural University, Anjora, Durg 491001 (Chhattisgarh), India, for extending the financial and other facilities to accomplish the study.

\section{Competing interests}

The authors declare that they have no competing interests.

\section{References}

1. Urquhart, G. M. (1980). Application of immunity in the control of parasitic disease. Vet. Parasitol. 6: 217-239.

2. Sykes, A. R. (1994). Parasitism and production in farm animals. Anim. Prod. 59:155-172.

3. Van Wyk, J.A., Malan, F.S. \& Bath, G.F. (1997). Rampant anthelmintic resistance in sheep in South Africa - What are the Options? In: Managing Anthelmintic Resistance in Endoparasites, (Eds. Van Wyk, J.A. \& Van Schalkwyk, P.C.) Workshop held at the $16^{\text {th }}$ Int. Conference of the WAAVP, Sun City, South Africa. pp. 51-63.

4. Waller, P.J. (1999). International approaches to the control of nematode parasites of livestock. Int. J. Parasitol. 29: $155-164$

5. Jackson, F., Bartley, D., Bartley, Y. and Kenyon, F. (2009). Worm control in sheep in the future. Small Rum. Res. 86: 4045.

6. West, D. M., Pomroy, W. E., Kenyon, P. R., Morris, S. T., Smith, S. L. and Burnham, D. L. (2009). Estimating the cost of subclinical parasitism in grazing ewes. Small Rum. Res. 86: 84-86.

7. Vatta, A.F., Waller, P.J., Githiori, J.B., Medley, G.F. (2009). The potential to control Haemonchus contortus in indigenous South African goats with copper oxide wire particles. Vet. Parasitol. 162 (3-4): 306-313.

8. Coop, R. L. and Holmes, P. H. (1996). Nutrition and Parasitic Interaction. Int. J. Parasitol. 26: 951-962.

9. Van Houtert, M.J.F. and Sykes, A.R. (1996). Implications of nutrition for the ability of ruminants to withstand gastrointestinal nematode infections. Int. J. Parasitol. 26: 1151-1168.

10. Athanasiadou, S., Kyriazakis, I., Giannenas, I., Papachristou, T.G. (2009). Nutritional consequences on the outcome of parasitic challenges on small ruminants. In: Papachristou, T.G., Parissi, Z.M., Ben Salem, H., MorandFehr, P. (Eds.), Nutritional and Foraging Ecology of Sheep and Goats. CIHEAMFAO- NAGREF, Zaragoza, Spain, pp. 29-40.

11. Maherisis, N., M. Chaichi Semsari, B. Eshratkhah, M. Sadaghian, A. Gorbani and Hassanpour, S. (2011). Evaluation of the effects of Quebracho condensed tannin on faecal egg counts during naturally acquired mixed nematode infections in Moghani sheep. Annals Biol. Res. 2 (2): 170174.

12. Sadaghian, M., S. Hassanpour, N. Maheri-Sis, B. Eshratkhah, A. Gorbani and Chaichi-Semsari, M. (2011). Effects of different levels of wattle tannin drenches on faecal egg counts during naturally acquired mixed nematode infections in Moghani sheep. Annals Biol. Res. 2 (1): 226230.

13. Dubey, C. S., Mondal, B. C., Tiwari, D. P., Kumar, A. and Yadav, C. L. (2011). Effect of plane of nutrition on nutrient utilization, Haemato-biochemical parameters and immune response in Haemonchus contortus infected sheep. Anim. Nutr. Feed Technol. 11:27-39.

14. Pathak, A.K. (2011). Nutritional status and performance of ruminants as influenced by gastrointestinal nematodes: An Overview. N. E. Vet. XI (3): 20-26.

15. Sahoo, A., Khan, F.A. and Karim, S.A. (2011). A review on nutrition and gastro-intestinal nematode parasitism: Interaction and implications in ruminant livestock. Indian J. Small Rumin. 17 (1): 1-20.

16. Haile, A., Anindo, D.O., Tembely, S., Mukasa-Mugerwa, E., 
Tibbo, M., Yami, A., Baker, R.L. and Rege, J.E.O. (2004). Effects of dietary protein supplementation and infection with gastrointestinal nematode parasites on some nutritional and metabolic parameters in Ethiopian Menz and Horro sheep. Livestock Prod. Sci., 91: 183-195.

17. Bricarello, P.A., Amarante, A.F.T., Rocha, R.A., Cabral, F.S.L., Huntley, J.F., Houdijk J.G.M., Abdalla A.L. and Gennari S.M. (2005). Influence of dietary protein supply on resistance to experimental infections with Haemonchus contortus in the Ile de France and Santa Ines lambs. Vet. Parasitol., 134: 99-109.

18. Knox, M. R., Torres-Acosta, J.F.J., Aguilar-Caballero, A. J. (2006). Exploiting the effect of dietary supplementation of small ruminants on resilience end resistance against gastrointestinal nematodes. Vet. Parasitol. , 139: 385-393.

19. Marume, U., Chimonyo, M., Dzama, K. (2011). A preliminary study on the responses to experimental Haemonchus contortus infection in indigenous goat genotypes. Small Rumin. Res. 95 (1): 70-74.

20. Jackson, F. (2008). Nutrition and immunity of nematodes of livestock. Parasite Immunol., 30 (2): 61-2.

21. Anthanasiadou, S., Houdijk, J. and Kyriazakis, I. (2008). Exploiting synergisms and interactions in nutritional approaches to parasite control in sheep production. Small Rum. Res., 76: 2-11.

22. Hoste, H., Torres-Acosta, J.F.J. and Aguilar-Caballero, A.J. (2008). Nutrition-parasite interactions in goats: is immunoregulation involved in the control of gastrointestinal nematodes? Parasite Immunol., 30: 79-88.

23. Snedecor, G.W. and Cochran, W.B. (1994). Statistical methods, $8^{\text {th }}$ edn, The Iowa State University Press, Ames, Iowa, USA.

24. National Research Council, NRC. (2007). Nutrient Requirements of Small Ruminants. National Academic Press, Washington.

25. Van Houtert, M. F. J., Barger, I. A., Steel, J. W., Windon, R. G. and Emery, D. L. (1995). Effects of dietary protein intake on responses of young sheep to infection with Trichostrongylus colubriformis. Vet. Parasitol. 56: 163-180.

26. Israf, D.A., Coop, R.L. and Stevenson, L.M. et al. (1996). Dietary protein influences upon immunity to Nematodirus battus infection in lambs. Vet. Parasitol. 61: 273-286.

27. Dutta, F.U., Nolan, J.V., Rowe, J.B., Gray, G.D. (1998). Protein supplementation improves the performance of parasitised sheep fed a straw-based diet. Int. J. Parasitol., 28: 1269 .
28. Gray, G.D., Woolaston, R.R.and Eaton, B. (1995). Breeding for resistance to infectious diseases in small ruminants. Canberra: ACIAR.

29. Douch, P.G.C. (1996). Phenotypic markers for selection of nematode-resistance sheep. Int. J. Parasitol. 26: 899-911.

30. Elsasser, T.H., Kahl, S., Stelle, N.C. and Rumsey, T.S. (1997). Nutritional modulation of somatotropic axiscytokine relationships in cattle: a brief review. Comp. Biochem. Physiol. 116: 209-221.

31. Spurlock, M.E. (1997). Regulation of metabolism and growth during immune challenge: an overview of cytokine function. J. Anim. Sci. 75: 1773-1783.

32. Blackburn, H. D., Rocha, J. L. Figueredo, E. P. Berne, M. E. Viera, L. S. Cavalcante A. R. and Rosa. J. S. (1991). Interaction of parasitism and nutrition and their effects on production and clinical parameters in goats. Vet. Parasitol. 40: 99-112.

33. Sykes A. R. and Coop, R. L. (1977). Intake and utilization of food by growing sheep with abomasal damage caused by daily dosing with Ostertagia circumcincta larvae. J. Agric. Res. 26: 1063-1072.

34. Fox, M. T. D., Gerelli, S. R. Pett, D. E. Jacob M. and GILL. D. L. (1989). Ostertagia ostertagi infection in the calf: effects of a trickle challenge on appatite, digestibility, rate of passage of digesta and live weight gain. Res. Vet. Sci. 47: 294-298.

35. Preston, J. M. and Allonby, E. W. (1978). The influence of breed on the susceptibility of sheep and goat to a single experimental infection with Haemonchus contortus. Vet. Rec.103: 509-512.

36. Abbott, E.M., Parkins, J.J. and Holmes, P.H. (1988). Influence of dietary protein on the pathophysiology of haemonchosis in lambs given continuous infections. Res. Vet. Sci., 45: 41.

37. Etter, E., Hoste, H., Chartier, C., Pors, I., Koch,C., Broqua, C. and Coutineau, H. (2000). The effect of two levels of dietary protein on resistance and resilience of dairy goats experimentally infected with Trichostrongylus colubriformis: Comparison between high and low producers. Vet. Res. 31:247-258.

38. Kahn, L. P., Kyriazakis, I., Jackson, F. and Coop, R. L. (2000). Temporal effects of protein nutrition on the growth and immunity of lambs infected with Trichostrongylus colubriformis. Int. J. Parasitol. 30: 193-205.

39. Coop, R. L. and Kyriazakis, I. (2001). Influence of host nutrition on the development and consequences of nematode parasitism in ruminants. Trends Parasitol. 17: 325-330. 